Юридичні науки

УДК 347.962

Хмиз Мар'яна Василівна

доктор філософії

Львівський університет бізнесу та права

Хмыз Марьяна Васильевна

доктор философии

Львовский университет бизнеса и права

Khmyz Mariana

$P h D$

Lviv University of Business and Law

ORCID: 0000-0003-3553-8022

ПРАВО НА СПРАВЕДЛИВИЙ СУД В КОНТЕКСТІ СТАТТІ 6

КОНВЕНЦІЇ ПРО ЗАХИСТ ПРАВ ЛЮДИНИ І

ОСНОВОПОЛОЖНИХ СВОБОД

ПРАВО НА СПРАВЕДЛИВЫЙ СУД В КОНТЕКСТЕ СТАТЬИ 6

КОНВЕНЦИИ О ЗАЩИТЕ ПРАВ ЧЕЛОВЕКА И ОСНОВНЫХ

СВОБОД

\title{
RIGHT TO A FAIR TRIAL IN THE CONTEXT OF ARTICLE 6 OF THE \\ CONVENTION FOR THE PROTECTION OF HUMAN RIGHTS AND FUNDAMENTAL FREEDOMS
}

Анотація. На основі вивчення теорї та узагальнення судової практики у статті аналізуються основні положення статті 6 Конвениії про захист прав людини і основоположних свобод і розкривається їх зміст крізь призму практики Європейського суду з прав людини.

Ключові слова: суддя, суд, правосуддя, право на справедливий суд, європейські стандарти, демократичне суспільство, Конвениія про захист прав людини і основоположних свобод. 
Аннотация. На основе изучения теории и обобщения судебной практики в статье анализируются основные положения статьи 6 Конвенции о защите прав человека и основных свобод и раскрывается их содержание сквозь призму практики Европейского суда по правам человека.

Ключевые слова: судья, суд, правосудия, право на справедливый суд, европейские стандарты, демократическое общество, Конвениия о защите прав человека и основных свобод.

Summary. Based on the study of the theory and generalization of judicial practice, in the article analyzes the main provisions of Article 6 of the Convention for the Protection of Human Rights and Fundamental Freedoms and reveals their content through the prism of the practice of the European Court of Human Rights.

Key words: judge, court, justice, right to a fair trial, European standards, democratic society, Convention for the Protection of Human Rights and Fundamental Freedoms.

Як відомо, однією із найважливіших конституційних гарантій забезпечення та захисту прав та свобод особи є закріплення права на судовий захист [1-3]. Статтею 55 Конституції України [4] встановлено, що «... права i свободи людини i громадянина захищаються судом. ...Кожному гарантується право на оскарження в суді рішень, дій чи бездіяльності органів державної влади, органів місцевого самоврядування, посадових і службових осіб» [4]. Тут варто погодитись 3 думкою С. Рурич [1], що «зміст цього права полягає в тому, що кожен має право звернутися до суду, якщо його права чи свободи порушені або порушуються, створено або створюються перешкоди для їх реалізації або мають місце інші ущемлення прав та свобод. Зазначена норма зобов'язує суди приймати 
заяви до розгляду навіть у випадку відсутності в законі спеціального положення про судовий захист (п. 2 рішення Конституційного Суду України 25 грудня 1997 року по справі № 9зп)» [1].

Створення (формування) міжнародних механізмів гарантій основних прав i свобод людини $є$ одним із найбільших досягнень світового співтовариства у XX ст. Ці гарантії знайшли своє вираження і закріплення через загальносвітове визнання міжнародних договорів 3 прав людини, а також спеціальних органів, уповноважених здійснювати контроль (попередній, поточний, заключний) за дотриманням основних прав і свобод людини. Одним із найбільш ефективних і результативних серед таких органів є Європейський суд 3 прав людини (далі - ССПЛ) [1; 3]. Конвенція про захист прав людини і основоположних свобод 1950 року [5], $\epsilon$ правовою основою функціонування та діяльності ЄСПЛ [1; 3]. Конвенція була ратифікована Законом України «Про ратифікацію Конвенції про захист прав людини і основоположних свобод 1950 р., Першого протоколу та протоколів 2, 4, 7, 11 до Конвенції» від 17.07.1997 р. № 475/97/-ВР [5; 6].

Першорядними принципами Конвенції про захист прав людини i основоположних свобод свобод 1950 року [5] є верховенство права та належне здійснення правосуддя. Ці принципи також $є$ головними елементами права на справедливий суд, гарантований ст. 6 цієї Конвенції $[1-3 ; 5]$.

В 1-ій частині ст. 6 Конвенції про захист прав людини i основоположних свобод свобод 1950 року (далі - СКПЛ) [5] зазначено, що «1. Кожен має право на справедливий і публічний розгляд його справи упродовж розумного строку незалежним i безстороннім судом, встановленим законом, який вирішить спір щодо його прав та обов'язків цивільного характеру або встановить обгрунтованість будь-якого висунутого проти нього кримінального обвинувачення. Судове рішення проголошується публічно, але преса і публіка можуть бути не допущені в 
зал засідань протягом усього судового розгляду або його частини в інтересах моралі, громадського порядку чи національної безпеки в демократичному суспільстві, якщо того вимагають інтереси неповнолітніх або захист приватного життя сторін, або - тією мірою, що визнана судом суворо необхідною, - коли за особливих обставин публічність розгляду може зашкодити інтересам правосуддя» [5].

Виходячи з конструкції ч. 1 ст. 6 Конвенції [5], можна стверджувати, що у ній закріплено такі елементи права на судовий захист (1)-(6) [1] (С. Рурич): право на розгляд справи - (1); справедливість судового розгляду (2); публічність розгляду справи та проголошення рішення - (3); розумний строк розгляду справи - (4); розгляд справи судом, встановленим законом - (5); незалежність і безсторонність суду - (1).

В контексті цього доцільно зазначити, що судам необхідно мати на увазі, що виділяють 3-и види прав людини та основних свобод, гарантованих ЄКПЛ:

«- абсолютні права та свободи, які не можна порушувати в жодному разі - незалежно від умов, що існують у суспільстві (наприклад, право на життя; заборона катувань, нелюдського чи такого, що принижує гідність, поводження);

- права та свободи, до яких можна застосувати лише дуже вузькі (специфічні) обмеження (наприклад, право на особисту свободу та недоторканість; право на справедливий суд);

- права та свободи, користування якими може бути пов’язано 3 низкою дещо ширше сформульованих конфліктуючих інтересів держави та особи, наприклад ст.ст. 9-11, ст. 1 Першого протоколу, в яких частиною другою відповідної стані передбачений відповідні умови або підстави для обмеження цих прав. Скажімо, у статті 9 ЄКПЛ йдеться, що свобода сповідувати релігію або переконання підлягає лише таким обмеженням, які встановлені законом і $є$ необхідними в демократичному суспільстві в 
інтересах громадської безпеки, для охорони громадського порядку, здоров’я чи моралі або для захисту прав і свобод інших осіб; у статі 10 ЄКПЛ зазначено, що здійснення свободи вираження поглядів, оскільки воно пов'язане з обов'язками і відповідальністю, може бути предметом таких формальностей, умов, обмежень або санкцій, що встановлені законом і $є$ необхідними в демократичному суспільстві в інтересах національної безпеки, територіальної цілісності або громадського спокою, для охорони порядку або запобігання злочинам, для охорони здоров’я або моралі, для захисту репутації або прав інших осіб, для запобігання розголошенню конфіденційної інформації або для підтримання авторитету і безсторонності суду» [7] (В. Яцина, А. Киричок).

Аналізуючи практику Свропейського суду 3 прав людини щодо України, підтримуючи думку I. Коваль [8], можна зробити загальний висновок [1-12]:

1. Причини порушення прав людини і громадянина частіше за все полягають у недосконалому законодавстві України i/aбо в його практичному застосуванні державними органами та судовими інстанціями.

2. Враховуючи практичні кроки України на шляху до утвердження верховенства права та останні позитивні тенденції в українському правовому полі, можна сподіватись, що застосування положень Конвенції про захист прав людини і основоположних свобод та практики Суду з прав людини національними органами та судовими інстанціями дозволять у майбутньому уникати констатації Європейським судом порушення Україною положень Конвенції про захист прав людини і основоположних свобод свобод 1950 року.

\section{Література}

1. Рурич С. В. Право на справедливий суд в контексті статті 6 Конвенції про захист прав людини i основоположних свобод 1950 року. 
International Electronic Scientific Journal “Science Online” http://nauka-online.com/

10.07.2018 // Офіційний веб-сайт Південно-Західного міжрегіонального управління Міністерства юстиції (м. ІваноФранківськ). URL: https://pzmrujust.gov.ua/yurydychni-konsultatsii/1437pravo-na-spravedlyvyi-sud-v-konteksti-statti-6-konventsii-pro-zakhystprav-liudyny-i-osnovopolozhnykh-svobod-1950-roku-10072018 (дата звертання: 01.05.2021р.).

2. Мазур М. В., Тагієв С. Р., Беніцький А. С., Кострицький В. В. Тлумачення та застосування Конвенції про захист прав людини й основоположних свобод Європейським судом 3 прав людини та судами України: навчальний посібник / [Відп. ред. канд. іст. наук, доц. B. М. Карпунов]. Луганськ: PBВ ЛДУВС, 2006. 600 с. URL: https://helsinki.org.ua/files/docs/1251638730.pdf (дата звертання: 01.05.2021 p.).

3. Коконєва I. Право на справедливий суд у рішеннях ЄСПЛ // Правова система України в умовах європейської інтеграції: погляд студентської молоді: Зб. тез доп. IV Міжнародної студ. наук. конференції (м. Тернопіль, 15 травня 2020 р.) / редкол.: С. В. Банах, А. В. Грубінко, О. Є. Гомотюк та ін. Тернопіль: ТНЕУ, 2020. С. 114-116. URL: http://dspace.wunu.edu.ua/handle/316497/40600 (дата звертання: 01.05.2021 p.).

4. Конституція України: прийнята на п'ятій сесії Верховної Ради України 28 червня 1996 р. (із змінами та доповненнями). URL: http://zakon.rada.gov.ua/laws/show/254к/96-вp (дата звертання: 01.05.2021 p.).

5. Конвенція про захист прав людини і основоположних свобод 1950 року: Ратифіковано Законом України від 17.07.1997 р. № 475/97/-ВР (i3 змінами та доповненнями).

URL: https://zakon.rada.gov.ua/laws/show/995 004 (дата звертання: 01.05.2021 p.). 
6. Про ратифікацію Конвенції про захист прав людини i основоположних свобод 1950 р., Першого протоколу та протоколів 2, 4, 7, 11 до Конвенції: Закон України від 17.07.1997 р. № 475/97/-ВР (iз змінами та доповненнями).

URL: https://zakon.rada.gov.ua/laws/show/475/97-\%D0\%B2\%D1\%80\#Text (дата звертання: 01.05.2021 р.).

7. Яцина В. Б., Киричок А. В. Аналіз застосування практики Свропейський суд 3 прав людини за 2014 // Офіційний веб-сайт Апеляційного суду Харківської області. URL: https://hra.court.gov.ua/sud2090/inf_court/generalization/uzag1517 (дата звертання: 01.05.2021 р.).

8. Коваль I. Право на справедливий суд: практика Європейського суду 3 прав людини щодо України // Офіційний веб-сайт Міністерства юстиції України. URL: https://minjust.gov.ua/m/str_7474 (дата звертання: 01.05.2021 р.).

9. Фулей Т. І. Застосування практики Свропейського суду з прав людини при здійсненні правосуддя: Науково-методичний посібник для суддів. 2-ге вид. випр., допов. Київ, 2015. 208 с. URL: https://www.osce.org/files/f/documents/4/7/232716.pdf (дата звертання: 01.05.2021 p.).

10. Караман I. В., Козіна В. В. Свропейський суд 3 прав людини, Європейська конвенція з прав людини та індивідуальні заяви: перше знайомство. Київ: BAITE, 2015. 136 с. URL: https://kmkdka.com/sites/default/files/files/posibnyk_yespl.pdf I (дата звертання: 01.05.2021 р.).

11. Сопільник Р. Л. Право на справедливий суд у контексті практики Європейського суду з прав людини // Митна справа. 2014. № 1(2.1). С. 3-10. URL: http://nbuv.gov.ua/UJRN/Ms $2014 \quad 1 \% 282.1 \% 29 \quad 3 \quad$ (дата звертання: 01.05.2021 р.). 
International Electronic Scientific Journal "Science Online” http://nauka-online.com/

12. Сопільник Р. Л. Методологія забезпечення права на справедливий суд у світлі європейської інтеграції України: теоретичні та організаційні аспекти: монографія // Львівський університет бізнесу та права. Львів: Видавництво Львівської політехніки, 2017. 459 с. 